\title{
Article
}

\section{Development and Confirmatory Factor Analysis of the Non-Violent and Violent Offending Behavior Scale (NVOBS)}

Thornton, Abigail, Graham-Kevan, Nicola and Archer, John

Available at http://clok.uclan.ac.uk/13402/

Thornton, Abigail ORCID: 0000-0002-6619-2864, Graham-Kevan, Nicola

ORCID: 0000-0003-0621-3093 and Archer, John ORCID: 0000-0003-0483-1576 (2012) Development and Confirmatory Factor Analysis of the Non-Violent and Violent Offending Behavior Scale (NVOBS). Aggressive Behavior, 39 (3). pp. 171-181. ISSN 0096-140X

It is advisable to refer to the publisher's version if you intend to cite from the work. http://dx.doi.org/10.1002/ab.21468

For more information about UCLan's research in this area go to http://www.uclan.ac.uk/researchgroups/ and search for <name of research Group>.

For information about Research generally at UCLan please go to http://www.uclan.ac.uk/research/

All outputs in CLoK are protected by Intellectual Property Rights law, including Copyright law. Copyright, IPR and Moral Rights for the works on this site are retained by the individual authors and/or other copyright owners. Terms and conditions for use of this material are defined in the policies page.

\section{CLoK}

Central Lancashire online Knowledge www.clok.uclan.ac.uk

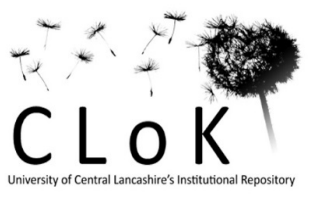




\begin{tabular}{|c|c|c|c|c|}
\hline \multirow{2}{*}{ td } & Journal & MSP No. & Dispatch: January 28,2013 & CE: Dinesh \\
\hline & $\mathrm{AB}$ & 11-115.R1(21468) & No. of Pages: 11 & PE: Adrianne Cook \\
\hline
\end{tabular}

\section{INTRODUCTION}

General $^{\mathrm{Q} 2}$ violence and non-violent behavior are frequently examined together in the criminological literature. Intimate Partner Violence (IPV) is generally studied separately from other types of crime as it is perceived to be a unique and specialist type of crime warranting its own research, theories and interventions (Daly \& Wilson, 1988; Dobash \& Dobash, 1992; Hotaling, Straus, \& Lincoln, 1990; Gelles \& Straus, 1979; Giles-Sims, 1983). In contrast with this, Gottfredson and Hirschi $(1990,2007)$ concluded that offenders have a propensity to commit a wide variety of criminal acts, and specialism in one type or another is quite rare. Similarly, the longitudinal research by Farrington et al. (2006) found that self-reported offenders tended "to be deviant in many aspects of their lives." A review of criminal careers research (DeLisi \& Piquero, 2011, p. 291) again found that "virtually all offenders are generalists." These sources all suggest that offenders are likely to be criminal generalists rather than specialists, and that the perpetration of violent and nonviolent offending is likely to overlap. There is at present no comprehensive measure that combines both violent and non-violent offenses. It was the purpose of this study

\section{Development and Confirmatory Factor Analysis of the Non-Violent and Violent Offending Behavior}

The purpose of this research was to develop a psychometrically sound measure of violent and non-violent offending, suitable for violence, theft, and criminal damage), which were confirmed with acceptable fit indices. The five-factor model applied to both . This new measure is a potentially valuable research tool for investigating people's involvement in violent and non-violent erties of scales, and confirming the category groupings using CFA : : : : : : : : : : : : : : : : : : : : : : : : : : : : : Keywords: domestic violence; general violence; offending; sex differences; scale development

to design such a measure so as to facilitate research on the generality of offending.

\section{Measuring IPV, Violent, and Non-Violent Crime}

Although the three offense areas are usually studied separately, some research has examined them together. Moffitt, Kreuger, Caspi, and Fagan (2000) investigated partner violence and general crime in 21-year-old men and women. Partner violence was measured using 13 items which consisted of the nine physical assault items from the original Conflict Tactics Scale (Straus, 1979), plus four new items, involving twisting the partner's arm, forced sex, shaking the partner, and throwing you are the partner bodily (Moffitt et al., 1997). The Self-Report Delinquency interview was used to measure general crime. General violence was measured using five items. Non-violent offending was split into three categories; theft (12 items), fraud (9 items), and vice (23 items). The

* Correspondence to: $\underline{\text { Abigail }}{ }^{\mathrm{O}}$ Thernten, Sehool of Psychology, Darwin Building, University of Central Lancashire, Preston, Lancashire PR1 2HE, United Kingdom. E mail: ajthornten@uclan.ac.uk

Received 20 July 2012; Accepted 17 December 2012

Published online in Wiley Online Library (wileyonlinelibrary.com). DOI: $10.1002 / \mathrm{ab} .21468$ 


\section{Thornton et al.}

researchers found that many perpetrators of partner violence also engaged in physical aggression towards.

Straus and Ramirez (2004) investigated the violent and non-violent criminal history of male and female IPV perpetrators. They measured partner violence using the 12-item physical assault scale from the CTS2 (Straus, Hamby, Boney-McCoy, \& Sugarman, 1996). These 12 items consisted of 5 minor assault items and 7 severe assault items. Criminal history was measured by four items, two involving violent crime (physical attack and carrying a hidden weapon), and two involving stealing. These four questions were asked for crime perpetrated before and after age 15 , so that there were eight items in total. The research found that a prior criminal history predicted IPV perpetration, and the relationship was stronger for prior violent crime than for property crime.

Where previous research has involved the three offense types (violent, partner violent and non-violent crime) different measures, with different response formats have been used to assess each one, with some being very brief (e.g., Straus \& Ramirez, 2004). The problem with using different measures with different response formats is that the results are not directly comparable as there will be different variance in the units of measurement for each variable, which introduces different elements of measurement error and bias. The problem with using scales with different numbers of items is that it is not possible to ascertain if the higher prevalence or frequency of offending is simply due to there being more items on that particular scale. It is also difficult to compare between different offenses if different measures have been used. Other potential problems include not separating general violence and non-violent offending (e.g., Moffitt et al., 2000), precluding the exploration of differences between general violence and non-violent crimes. The current study seeks to overcome these limitations by creating a scale that allows the three offense types to be measured and analyzed as three separate domains.

Although there are other comprehensive measures, such as the British Crime Survey (BCS) for the UK, the National Crime Victimization Survey (NCVS) for the US, and the Uniform Crime Reporting Survey (UCRS) for Canada, the questionnaire developed in this study is much shorter and more suitable for use in psychological research, where it can be administered alongside other measures. Problems associated with the existing measures include the national crime surveys only measuring crimes that have a direct victim, so that victimless crimes (such as drug taking) are excluded. These are included in the current measure, making it a more comprehensive assessment of self-reported offending behavior. Crime surveys measure only crime victimization, whereas the current questionnaire also measures offense perpetration. It therefore provides a comprehensive measure for use in psychological research.

To overcome the limitations in existing measures, outlined above, a measure is required which has comparable questions for all three offense types, which uses the same response method throughout, and has a wide variety of criminal acts included, so that the profile of men's and women's offending can be adequately captured. The current research involves the development of such a scale.

\section{The Overlap}

This divide between research on IPV and other crime may be borne out of feminist conceptualizations, where IPV, unlike other violent and non-violent crime, is viewed as being uniquely the consequence of patriarchy, and is therefore solely (or largely) regarded in terms of men aggressing against women (e.g., Dobash \& Dobash, 1980, 1998, 2004; Dobash, Dobash, Cavanagh, \& Lewis, 1998; Dobash, Dobash, Wilson, \& Daly, 1992; Henning, Jones, \& Holdford, 2003). The evolutionary view parallels this, highlighting the uniqueness of intersexual aggression as the consequence of mateguarding arising from paternity uncertainty (e.g., Wilson \& Daly, 1992, 1996). From both the feminist and evolutionary perspectives, IPV is portrayed as a unique and specialized crime due to victim choice, in that victims are female and in an intimate relationship with a male perpetrator (but see Archer, 2012; Felson, 2002; GrahamKevan \& Archer, 2009).

In contrast, research from a more psychological or criminological perspective has recognized the heterogeneity of IPV perpetrators, with some being exclusively violent within their intimate relationship and others being violent in more than one context, that is, their violence is not limited to their partner but occurs out of the home as well. Research dating back to the 1980s (e.g., Cadsky \& Crawford, 1988; Fagan, Stewart, \& Hansen, 1983; Gondolf, 1988; Shields, McCall, \& Hanneke, 1988) has identified this overlap in the perpetration of general violence and IPV. These classifications have more recently been confirmed for both male (HoltzworthMunroe, Meehan, Herron, Rehman, \& Stuart, 2000) and female (Babcock, Siard, \& Miller, 2003) perpetrators. Babcock et al. (2003) concluded that the findings for women parallel those for men, with perpetrators of IPV being a heterogeneous group. Male typologies of violent behavior have been developed and extensively researched (e.g., Holtzworth-Munroe \& Stuart, 1994), but consideration of female typologies and how they relate to the male research is sparse. Although an association between types of violent offending has long been identified, investigation into the overlap of 
offending behavior in men and women has largely been neglected, particularly for women.

\section{Risk Factors for IPV, Violent, and Non-violent Crime}

Previous research has examined the criminal histories of men and women who perpetrate IPV, and has found that a substantial subgroup of these men and women have prior convictions for crimes unrelated to partner abuse (Babcock et al., 2003; Busch \& Rosenberg, 2004; Buzawa, Hotaling, Klein, \& Byrne, 1999; DeLucia, Owens, Will, \& McCoin, 1999; Henning \& Feder, 2004; Moffitt et al., 2000, 2001). This research provides evidence for the interrelatedness of the three different types of crimes, and provides a rationale for assessing them all in the same sample.

Additionally, research has shown that risk factors for aggressive and antisocial behavior tend to be shared by both boys and girls $\left(\underline{B r o i d y}^{\mathrm{Q} 3}\right.$ et al., 2003; Côté, Tremblay, Nagin, Zoccolillo, \& Vitaro, 2002; Moffitt et al., 2001), and that the same influences predict both general and partner aggression in men and women (Moffitt et al., 2000; Tremblay et al., 2004). These shared risk factors include low self-control, negative emotionality, low intelligence and empathy deficits, and suggest that the different forms of aggression are developmentally similar and likely to co-occur.

Aggressive adults are highly likely to have a history of aggressive behavior beginning in childhood (Conradi, Geffner, Hamberger, \& Lawson, 2009; Hay, 2005). Longitudinal research has found that men and women with a history of conduct problems are more likely to enter into a relationship with a violent partner, and are likely to perpetrate violence towards their partners, in excess of their own victimization (Moffitt et al., 2001), suggesting that IPV "is but another expression of an earlier emerging antisocial propensity" (Moffitt et al., 2001, p. 65). Longitudinal data have demonstrated that the overlap between IPV and general violence perpetration is similar for men and women, showing that partner-violent men and women at age 21 were more likely to aggress against non-family members than those who were non-violent to their partners (Moffitt et al., 2000). This research demonstrates that different types of aggressive and antisocial behaviors share similar risk factors and are likely to co-occur in both sexes.

\section{Studying Violent and Non-Violent Offending of University Students}

Although students are generally thought to be relatively law-abiding, especially with regards to violent crime, there is one violent crime which has been found to be prevalent in student populations, and that is IPV (e.g., Fiebert \& Gonzalez, 1997; Foo \& Margolin, 1995;
Nabors, 2010; Riggs \& O’Leary, 1996; Straus, 2008; Straus \& Ramirez, 2004; White \& Koss, 1991). Therefore, using this population allows us to examine the overlap of self-reported offending in a non-selected sample. Although violent and non-violent crime in university students may be low compared with other populations, research shows that these behaviors are present: they may just be less frequent in students. Therefore, other samples are likely to show similar patterns of offending, only at higher rates. Statistics show that students form quite a large part of the population in many countries, for example, in the UK there are approximately 2.5 million students (Higher Education Statistics Agency: HESA, 2011). Universities are employing strategies to widen participation to make university more accessible to underrepresented groups, and HESA collects and provides statistics on this. The university that this sample was taken from is above the UK average for widening participation to underrepresented groups, including those from low participation neighborhoods (top 10), and those from lower socioeconomic statuses (top 25) (HESA, 2011). Therefore, the population from which the current sample was derived has a reasonably wide demographic representation for a University sample.

In summary, the aim of this research is to create a psychometrically sound scale that allows the separate assessment of violent and non-violent offending in men and women. To achieve this, we conducted exploratory factor analysis, and then confirmatory factor analysis, on the Non-violent and Violent Offending Behavior Scale (NVOBS: Thornton, Graham-Kevan, \& Archer, 2010) for men and women, together and then separately, to create a scale appropriate for use with both sexes. Additionally the scale was assessed for reliability.

\section{METHOD}

\section{Item Selection}

Potential items were selected by reviewing existing measures of delinquency (which included items relating to general violence and non-violent offending) and partner violence and, in order to include a broad range of both violent and non-violent criminal acts (e.g., Bendixen \& Olweus, 1999; Borjesson, Aarons, \& Dunn, 2003; Dahlberg, Toal \& Behrens, 1998; Huizinga, Esbensen, \& Weiher, 1991; Mak, 1993; Moffitt \& Silva, 1988; Moffitt et al., 1997; Straus, 1979; Straus, Hamby, Boney-McCoy, \& Sugarman, 1996). Initially, 119 items were selected from the literature review and a pilot study was conducted to investigate the prevalence of the behaviors in women as violent and criminal scales tend to be developed on men. A number of items from the earlier measure used in the pilot study were eliminated due to 
very low endorsement (endorsed by $<1 \%$ of the sample; e.g., Used a weapon on someone, Choked partner, Sold cocaine, Arson, Stole over £100), suggesting that these behaviors may not be characteristic of university students. Therefore, a final pool of 70 items was generated and used in the current research. The general violence and IPV items were duplicates of each other in order that the same items were captured. Items were adapted for use in the current study so that they all had the same response options.

\section{Data Collection}

Data were collected from a total of 653 participants ( 300 [45.9\%] men and 353 [54.1\%] women). A subset of the present sample was published as a study investigating predictors of offending (Thornton, Graham-Kevan, \& Archer, 2010). The present analysis does not overlap with what was reported there. The study was approved by the University of Central Lancashire Ethics Committee. Participants were either undergraduate or postgraduate students from a variety of courses, recruited on campus at a British university. Inclusion criteria comprised: being in a heterosexual relationships for at least one month in the past 12 months, and being over 18 years of age. Age ranged from 18 to 56 and the mean age was 22.14 years (men: 22.22; women: 22.08). It is important that men and women were matched for age as research has shown that violence (e.g., Archer, 2004) and offending (Gottfredson \& Hirschi, 2007) decrease with age: therefore failure to match men and women on age could distort sex differences. There was no significant sex difference for age $(t(651)=.17$, $P=.87)$. Participants who consented were administered questionnaires containing the 70 items, and were asked to report the extent to which they had been violent towards their partners, violent towards others, and engaged in nonviolent offenses in the past 12 months (see Appendix 1 for instructions to participants). The 12-month time period is commonly used in both studies of IPV (e.g., Straus, 1979; Straus, Hamby, Boney-McCoy, \& Sugarman, 1996), and in general aggression research (e.g., Richardson \& Green, 1999, 2003). Items were answered on a 7-point scale of 0 (never happened) to 6 (happened more than 20 times). Straus et al. (1996) recommend recoding the responses to weight the data by creating midpoints for each of the items as follows: 4 (3-5 times), 8 (6-10 times), 15 (11-20 times), and 25 (more than 20 times: 25 is an assumed midpoint and is recommended by Straus et al., 1996, p. 305). Therefore, this procedure was adopted here.

\section{RESULTS}

For the purposes of factor analysis, the sample was randomly divided into two sub-samples, one used to conduct exploratory factor analysis $(n=337$, men $=152$, women $=185$ ) and the other used to validate the structure using confirmatory factor analysis $(n=$ 316 , men $=148$, women $=168$ ). To examine potential sex differences, exploratory factor analyses were also conducted separately for men and women. The sexes were matched for age within each subsample.

The dataset was initially assessed for suitability for factor analysis. The Kaiser-Meyer-Olkin (KMO) measure of sampling adequacy ranges from 0 to 1 , and the result should be .6 or above to show appropriateness for factor analysis (Field, 2009; Kaiser, 1974; Tabachnick \& Fidell, 2007). For this study $\mathrm{KMO}=.76$, which is above the recommended minimum value. Bartlett's test of sphericity was statistically significant $\left(\chi^{2}(903)=\right.$ 6515.93, $P<.001)$, indicating that the inter-item correlations were sufficiently large for principal component factor analysis. Therefore, the data are suitable for factor analysis.

A principal component analysis (PCA) with Varimax (orthogonal) rotation was conducted. Oblique rotation (Direct Oblimin) was also tested: however, the interfactor correlations were all weak (.2 or below). Therefore, the decision to use an orthogonal rotation method was justified (Pedhazur \& Schmelkin, 1991).

The number of factors to retain is often determined by a Scree test (Cattell, 1966; Klein, 1994). However, the Scree test can be subject to ambiguity where there is either no clear break in the curve or where there appears to be more than one definite break. Since the Scree plot was ambiguous in this case, Horn's Parallel Analysis was used (Horn, 1965). Parallel analysis (PA) calculates average eigenvalues from a random dataset that is based on the sample size and number of variables contained within the real dataset. The real eigenvalues are then compared with the random eigenvalues, and only those where the actual values are higher than the corresponding random values are retained (see Hayton, Allen, \& Scarpello, 2004 for an outline of the PA procedure). Following parallel analysis, five factors were retained for the final solution. Together these five rotated factors explained $42.95 \%$ of the total variance. By studying the items that load on to each factor, the five factors were labeled, as (1) general violence, (2) drug-related offenses, (3) IPV, (4) criminal damage, and (5) theft. Only items which loaded $>.4$ on to at least one factor (Stevens, 1992) were retained, and no items loaded on more than one factor. Factor 1 (general violence) contained 12 items, factor 2 (drugs) contained 5 items, factor 3 (IPV) contained 8 items, factor 4 (criminal damage) contained 4 items, and factor 5 (theft) contained 4 items. Because each factor is measuring a different offense related dimension, the factors will now be referred to as subscales. The factor loadings for each item, along 
with Eigenvalues and percentage variance explained by each subscale, are displayed in Table 1 for the final rotated solution.

Reliability analysis was used to measure the internal consistency of the subscales. Cronbach's alpha coefficient $(\alpha)$ is one of the most popular indicators of internal consistency (Field, 2009). Alphas for each subscale on the NVOBS ranged from acceptable to good, since all were above .7 (see Table 1). To examine potential sex differences, exploratory factor analyses were also conducted separately for men and women. Examination of the factor compositions and percentage variance explained suggested similarities between the sexes: therefore, data were combined for men and women.

\section{Confirmatory Factor Analysis}

The model fit of the five-factor solution was tested using confirmatory factor analysis, performed using AMOS version 18.0. Item parcels were used to reduce the number of individual items entered into confirmatory factor analysis, in order to increase the stability of parameter estimates (Holt, 2004). To create parcels, scale items were bundled by averaging items. Averaging keeps the means more interpretable and comparable regardless of the number of items in the bundle. One of the chief advantages of parceling is that it improves the subject to variable ratio. Table 1 shows the parcel placement for each item. Model fit was assessed using comparative fit index (CFI), root mean square error of approximation (RMSEA), and goodness of fit index (GFI). The current model was recursive and identified. Confirmatory factor analysis produced a model of good fit $\left(\chi^{2}=(55) 147.90\right.$, $P<.001$, RMSEA $=.07$, GFI $=.94, \mathrm{CFI}=.94)$. For completeness, the model fit of the three factor (general violence, IPV, and non-violent offending) conceptual model suggested in the introduction was also tested. The results showed that the three factor model was not as good a fit to the data as the five-factor model $\left(\chi^{2}=(62)\right.$ $303.00, P<.001$, RMSEA $=.08$, GFI $=.91$, CFI $=.91)$. Therefore, the five-factor model was selected as the final model.

\section{Further Analyses of the NVOBS Subscales}

Subscales were derived from the factors by totalling the items for each of the five resulting offending behavior subscales. The subscale totals were screened for outliers and normality (Tabachnick \& Fidell, 2007). Outliers were reduced so that extreme scores were one more than the next most extreme score. Descriptive statistics are provided for each subscale (i.e., general violence, drugrelated behavior, IPV, criminal damage, and theft) in Table 2.

It is evident from Table 2 that the data are overdispersed (standard deviations are higher than the
TABLE 1. Results of Principal Components Factor Analysis With Varimax Rotation $(n=337)$ of NVOBS for Men and Women Showing the Final Five-Factor Solution ${ }^{a}$

\begin{tabular}{|c|c|c|}
\hline Item & $\begin{array}{l}\text { Rotated } \\
\text { Factor } \\
\text { Loadings }\end{array}$ & Parcel \\
\hline \multicolumn{3}{|l|}{ Factor 1. General Violence (GV: 12 items) } \\
\hline 1. Kicked someone & .85 & GV1 \\
\hline 2. Hit someone with a fist & .77 & GV1 \\
\hline 3. Pushed grabbed or shoved someone & .75 & GV1 \\
\hline 4. Beat someone up & .70 & GV2 \\
\hline 5. Scratched someone & .67 & GV2 \\
\hline 6. Slammed/held someone against a wall & .65 & GV2 \\
\hline $\begin{array}{l}\text { 7. Hit or tried to hit someone with something } \\
\text { hard besides a fist }\end{array}$ & .63 & GV3 \\
\hline 8. Bit someone & .61 & GV3 \\
\hline 9. Threw something at someone & 61 & GV3 \\
\hline 10. Slapped someone & .58 & GV4 \\
\hline 11. Twisted someone's arm or hair & .57 & GV4 \\
\hline 12. Bent someone's fingers & .54 & GV4 \\
\hline Eigenvalue & 6.32 & \\
\hline$\%$ Variance explained & 14.71 & \\
\hline$\alpha$ & .89 & \\
\hline \multicolumn{3}{|l|}{ Factor 2. Drugs (5 items) } \\
\hline 13. Used ecstasy & .84 & D1 \\
\hline 14. Used cocaine/crack & .79 & D1 \\
\hline 15. Used speed & .77 & D1 \\
\hline 16. Used cannabis & .73 & D2 \\
\hline $\begin{array}{l}\text { 17. Gang of } 3+\text { fighting, causing } \\
\text { damage/disturbance }\end{array}$ & .61 & D2 \\
\hline Eigenvalue & 3.48 & \\
\hline$\%$ Variance explained & 8.09 & \\
\hline$\alpha$ & .79 & \\
\hline \multicolumn{3}{|l|}{ Factor 3. IPV ( 8 items) } \\
\hline 18. Kicked partner & .79 & IPV1 \\
\hline 19. Hit partner with fist & .76 & IPV1 \\
\hline 20. Slapped partner & .75 & IPV1 \\
\hline 21. Bent partners fingers & .68 & IPV2 \\
\hline 22. Threw something at partner & .63 & IPV2 \\
\hline 23. Pushed grabbed or shoved partner & .48 & IPV2 \\
\hline 24. Scratched partner & .45 & IPV3 \\
\hline 25. Twisted partners arm/hair & .43 & IPV3 \\
\hline Eigenvalue & 3.37 & \\
\hline$\%$ Variance explained & 7.83 & \\
\hline$\alpha$ & .74 & \\
\hline \multicolumn{3}{|l|}{ Factor 4. Criminal Damage (CD: 4 items) } \\
\hline 26. Damaged something in a public place & .67 & CD1 \\
\hline 27. Graffiti & .62 & CD1 \\
\hline 28. Broke windows of empty building & .55 & CD2 \\
\hline 29. Damaged others property on purpose & .46 & CD2 \\
\hline Eigenvalue & 2.90 & \\
\hline$\%$ Variance explained & 7.74 & \\
\hline 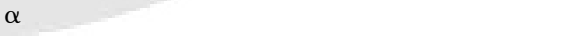 & .71 & \\
\hline \multicolumn{3}{|l|}{ Factor 5. Theft (T: 4 items) } \\
\hline 30. Stole $5-50$ & .67 & $\mathrm{~T} 1$ \\
\hline 31. Stole $<5$ & .66 & $\mathrm{~T} 1$ \\
\hline 32. Possessed stolen property & .48 & $\mathrm{~T} 2$ \\
\hline 33. Enter building to steal/damage & .44 & $\mathrm{~T} 2$ \\
\hline Eigenvalue & 2.40 & \\
\hline$\%$ Variance explained & 5.58 & \\
\hline Overall $\alpha$ & .70 & \\
\hline
\end{tabular}

${ }^{\mathrm{a}}$ Alphas were for scales based on the factors. 
TABLE 2. Means and Standard Deviations of NVOBS Subscales Overall and by Sex $(n=653)$, and $\chi^{2}$ and $d$ for Sex Differences

\begin{tabular}{|c|c|c|c|c|c|c|c|c|}
\hline \multirow[b]{2}{*}{ Factor } & \multicolumn{2}{|c|}{ Overall } & \multicolumn{2}{|c|}{ Men } & \multicolumn{2}{|c|}{ Women } & \multirow[b]{2}{*}{$\chi^{2}$} & \multirow[b]{2}{*}{$d^{\mathrm{a}}$} \\
\hline & Mean $(S D)$ & Range $(\% 0)$ & Mean $(S D)$ & Range $(\% 0)$ & Mean $(S D)$ & Range $(\% 0)$ & & \\
\hline GV & 7.85 (11.13) & $0-39(30.2 \%)$ & $10.44(12.26)$ & $0-39(23.7 \%)$ & $5.65(9.55)$ & $0-23(35.8 \%)$ & $21.89(1)^{*}$ & .43 \\
\hline IPV & $1.74(3.01)$ & $0-11(57.8 \%)$ & $0.84(1.85)$ & $0-9(69.3 \%)$ & $2.51(3.55)$ & $0-11(48 \%)$ & $51.32(1)^{*}$ & -.59 \\
\hline Drugs & $2.40(4.24)$ & $0-16(61.3 \%)$ & $3.64(5.52)$ & $0-16(56.3 \%)$ & $1.99(3.73)$ & $0-12(65.4 \%)$ & $10.97(1)^{*}$ & .35 \\
\hline $\mathrm{CD}$ & $0.79(1.62)$ & $0-5(74 \%)$ & $1.12(1.86)$ & $0-5(64.7 \%)$ & $0.50(1.31)$ & $0-5(81.9 \%)$ & $16.66(1)^{*}$ & .39 \\
\hline Theft & $1.00(1.82)$ & $0-6(69.7 \%)$ & $1.37(2.19)$ & $0-6(63 \%)$ & $0.68(1.35)$ & $0-4(75.4 \%)$ & $15.34(1)^{*}$ & .38 \\
\hline
\end{tabular}

${ }^{a}$ Minus sign indicates that women's values are higher than men's.

${ }^{*} P<.001$.

corresponding means). This sort of distribution is typically found in studies of IPV using the Conflict Tactics Scale and similar measures (Straus, 1979; Straus et al., 1996). The preferred method for such datasets, which are truncated at zero, highly skewed in the positive direction, and overdispersed (standard deviations are higher than the corresponding means), is negative binomial regression (Gardner, Mulvey, \& Shaw, 1995; Hilbe, 2007 ${ }^{4}$; Hutchinson \& Holtman, 2005). This has been used in recent studies of IPV (e.g., Archer, Fernández-Fuertes, \& Thanzami, 2010; Finkel, DeWall, Slotter, Oaten, \& Foshee, 2009), and was used in the present case to test for differences between the factor analysis and the confirmatory factor analysis subsamples on each of the five NVOBS subscales. The Goodness of Fit statistics were satisfactory as the Deviance value should be near 1 (general violence: Value/df $=1.11$; drugs: Value/df $=0.79 ; \mathrm{IPV}$ : Value $/ \mathrm{df}=0.84$; criminal damage: Value/df $=0.61$; theft: Value/df $=0.69$ ). There were no significant differences between the factor analysis and confirmatory factor analysis subsamples on each of the five NVOBS subscales: general violence (Wald $\chi^{2}(1)=0.97, P=.33$ ), drug offenses (Wald $\chi^{2}$ $(1)=0.07, P=.79)$, IPV (Wald $\chi^{2} \quad(1)=0.14$, $P=.71$ ), criminal damage (Wald $\chi^{2}(1)=.75, P=$ .39 ), and theft offenses (Wald $\chi^{2}(1)=0.13, P=.72$ ). Therefore, the data from the two subsamples were combined, and means, standard deviations, and frequencies of scores were calculated for each subscale overall, and for men and women separately.
Negative Binomial Regressions (NBR) were used to test for sex differences on the five NVOBS subscales (see Table 2 for the NBR results). The Goodness of Fit statistics were again satisfactory as the Deviance values were near 1 (general violence: Value/df $=1.11$; drugs: Value $/ \mathrm{df}=0.78$; IPV: Value $/ \mathrm{df}=0.85$; criminal damage: Value/df $=0.62$; theft: Value/df $=0.69)$. Men perpetrated higher levels of general violence (Wald $\chi^{2}(1)=$ $21.89, P<.001$ ), drug offenses (Wald $\chi^{2}(1)=10.97$, $P<.001$ ), criminal damage (Wald $\chi^{2}(1)=16.66$, $P<.001$ ), and theft offenses (Wald $\chi^{2}(1)=15.34$, $P<.001)$ than women, but women perpetrated significantly more IPV (Wald $\chi^{2}(1)=51.32, P<.001$ ) than men. According to Cohen's (1988) criteria, effect sizes (shown in Table 2) were small for drug offenses, theft and criminal damage, and medium for IPV and general violence.

\section{Intercorrelations Between the Five Offending Behaviors}

Table 3 shows the Pearson correlations between the five identified offense types separately for men and women to demonstrate the interrelatedness of offending for men and women. The results revealed small to moderate significant correlations between all offenses for women, and small to moderate significant correlations between most offenses for men. For men IPV was not correlated with drug offenses or criminal damage. Overall the correlational results suggest that men's and women's violent and nonviolent offending is interrelated,

TABLE 3. Pearson Correlations for All Five Categories of Offending Behavior for Men and Women

\begin{tabular}{|c|c|c|c|c|c|c|c|c|c|c|}
\hline & \multicolumn{5}{|c|}{ Men } & \multicolumn{5}{|c|}{ Women } \\
\hline & GV & IPV & Drugs & $\mathrm{CD}$ & Theft & $\mathrm{GV}$ & IPV & Drugs & $\mathrm{CD}$ & Theft \\
\hline $\mathrm{GV}$ & - & $.20^{*}$ & $.18^{*}$ & $.35^{*}$ & $.33^{*}$ & - & $.28^{*}$ & $.20^{*}$ & $.31^{*}$ & $.26^{*}$ \\
\hline IPV & & - & .03 & .01 & $.20^{*}$ & & - & $.23^{*}$ & $.21^{*}$ & $.23^{*}$ \\
\hline Drugs & & & - & $.38^{*}$ & $.40^{*}$ & & & - & $.35^{*}$ & $.39^{*}$ \\
\hline $\mathrm{CD}$ & & & & - & $.47^{*}$ & & & & - & $.43^{*}$ \\
\hline
\end{tabular}


and supports the theory that offenders are "cafeteria" criminals rather than specialists and are likely to be involved in a variety of criminal behavior where there is opportunity (Gottfredson \& Hirschi, 1990). There was no evidence of multicollinearity as there were no correlations above .70 .

\section{DISCUSSION}

The aim of this study was to develop a self-report measure of violent and non-violent offending behavior which could be used by researchers to investigate the range of self-reported offending behavior in men and women in non-forensic populations. Five factors measuring violent and non-violent offending behavior in men and women were identified. These were: general violence, IPV, drug-related behavior, criminal damage, and theft. These categories are similar to the Home Office crime categories, which cover violent crime, acquisitive crime, vandalism/criminal damage, and drug offenses (Home Office, 2010). The NVOBS was shown to be psychometrically sound, with the resulting subscales having moderate to good internal consistency. Therefore, the NVOBS should be a useful instrument for measuring offending behavior in non-selected samples such as the ones used in the present study.

The new questionnaire distinguishes the components of offending, and allows for comparisons to be made between male and female offending. Examining sex differences in the NVOBS factors has provided support for previous research. We found that men self-reported more general violence than women: this was an expected finding, as a large body of research shows that, outside of intimate relationships, men are more violent than women, at every age and for various measures (Archer, 2004, 2009; Eme, 2007, 2009, 2010; Moffitt et al., 2001). The finding that men are more generally violent than women fits with the sexual selection theory where intrasexual competition is motivated by status and resource acquisition, and so sex differences should be most evident during young adulthood to correlate with the peak of reproductive competition (Daly \& Wilson, 1988; Wilson \& Daly, 1985). The current sample comprised predominantly young adults as the mean age of the current sample was 22 years. Eme (2010) suggested that the sex difference in violent behavior occurs because men are more vulnerable than women to a "host of neurodevelopmental risk factors that in interaction with family and environmental adversity exponentially increase the probability of violent behavior" (p. 486).

We also found that women were more violent than men within intimate relationships, which also supports a large body of evidence. Research using unselected samples (such as student samples) shows that women can be as violent as men within intimate relationships, if not more so (Archer, 2000, 2002, 2006, 2012; Graham-Kevan \& Archer, 2003; Thornton, Graham-Kevan, \& Archer, 2010). This finding has been found for both "minor" violence (e.g., pushing, slapping, hitting) as well as "severe" types of violence (Ehrensaft et al., 2004; Lussier et al., 2009; Straus, 2008), except for the items "beat up" and "choke" where the majority of the perpetrators were men (Archer, 2002), and women were the perpetrator in only about a third of cases. Research has shown that both men and women underreport their perpetration of IPV compared to reports about their partners, but this bias is more pronounced for men (Archer, 1999), leading to sex differences being slightly more in the female direction for perpetrators' reports than for victims' reports (Archer, 2000).

Alternatively, the current findings may be related to male students having more to lose in terms of reputation by physically aggressing against their female partners: in a student sample, people live within close proximity of each other, so that any IPV is likely to be detected. Male IPV is not socially sanctioned in such groups, this makes it more likely female victims would seek helps and others would intervene on their behalf (Felson, 2002). Therefore, male students may have more to lose in a student sample than males in a community sample, and so they may inhibit their aggression towards their female partners, as the costs of not doing so are particularly high. Women's IPV is not viewed as negatively as men's and evokes less disapproval (Gerber, 1991), and therefore may attract less third party involvement. Men's inhibition and the costs of IPV perpetration being lower for women than men may instead facilitate women's violence towards her partner (George, 1994), which would result in less male perpetrators and more female perpetrators in a sample such as this.

We found that men perpetrated more non-violent offenses (drugs, criminal damage, and theft) than women, which supports existing research findings, such as those of Moffitt et al. (2001) and Steffensmeier and Allan (1996), who reported that men are generally more antisocial than women. The effect sizes were smallest for drug-related offenses, theft and criminal damage, and largest for IPV, and general violence, which is consistent with previous research (e.g., Moffitt et al., 2001; Smith \& Visher, $\left.1980^{\mathrm{Q} 5}\right)$. Recent research by Vaughn, Fu, et al. (2011) suggests that females are significantly more likely than males to abstain from engaging in the use of substances and from antisocial behavior, which is consistent with the current finding that men engage in significantly more non-violent and generally violent offenses than women. The sexual selection theory may also account for why men may be involved in more nonviolent crimes than women. Men may steal or 
damage resources in order to outcompete rivals and increase the likelihood of their own access to females (Kanazawa \& Still, 2000; Walsh, 2000).

The correlations revealed the interrelatedness of offending for men and women and showed that each offense, whether violent or nonviolent, was related to the perpetration of other offenses. All the results are consistent with previous research and theories which say that offenders are likely to be versatile, and unlikely to specialize in one particular type of crime (DeLisi \& Piquero, 2011; Farrington et al., 2006; Gottfredson \& Hirschi, 1990), particularly those classed as "the severe $5 \%$ " of offenders who are versatile and are found to engage in high levels of the majority of antisocial and violent behavior (Vaughn, DeLisi, et al., 2011, p. 79). The results are also consistent with the conclusions of $\underline{\text { Payne }^{\mathrm{Q}}}$, Higgins, and Blackwell (2010, p. 1015) that "partner abusers should be viewed and treated as general types of criminals rather than specific types of offenders" because those who are violent within relationships are also more likely to be violent towards others in other settings. Altogether, the current findings demonstrate the close association between violent and nonviolent offending in men and women, and show that violent and nonviolent offending tend not to occur in isolation and instead form an interrelated set of complex behaviors. The interrelatedness between the five types of crime for men and women builds the case for measuring them together to assess their comorbidity, which is essential for extending our knowledge regarding the onset, development, and underlying mechanisms related to the different aspects of offending behavior in men and women.

Howard and Dixon (2011) developed a classification of violent offenses to be used to predict violent reoffending as part of the Offender Assessment System (OASys). To create this violence predictor, they examined a number of the main violence risk assessment instruments and found that there were 22 separate approaches for classifying criminal acts as either violent or non-violent. None of these classifications included drug offences or theft, which were assessed in the current study. Howard and Dixon (2011) concluded that "this lack of consensus on the classification of violent criminal behavior is an important issue for developers of new violence risk measures." Therefore, their research has also identified a need for a comprehensive measure that classifies violent and non-violent offenses. The results from Howard and Dixon's study have confirmed that violent and nonviolent offenses overlap, as a history of criminal damage was found to predict future violent offending.

Studies such as the present one are limited in a number of ways. First, factor analysis itself has limitations. Factor analysis is a highly subjective procedure at a number of stages. The judgments made throughout the analysis including deciding which analytic method to use, which rotation method to use, and how many factors or items to retain or omit at each stage. However, we countered these limitations by confirming the same results using an alternative rotation method which indicated a robust solution. We also used parallel analysis to identify the number of factors to retain. This has been shown to be a more accurate method than using either Kaiser's Criterion or Cattell's Scree plot alone (Hayton et al., 2004). Furthermore, there can be any number of solutions and the interpretation of the solution is left to the researcher. There are also no external criteria against which to assess the validity of the solution. However, our use of CFA to confirm the NVOBS factor structure addresses this limitation. Acknowledging the limitations, both factor analysis and CFA have been widely used in scale development and are deemed to be very useful evaluative methods.

A further potential limitation is that self-reports were used. Self-reports can be affected by socially desirable responding, and participants may deliberately distort their responses by underreporting violent and antisocial acts in order to minimize their involvement. This has been found to be the case in the area of partner violence, where both men and women underreport their perpetration of IPV (Archer, 1999).

All participants in the current study were university students. Therefore, a non-student sample could also be used to establish norms and generalizability of the factor structure. Therefore, researchers using the NVOBS should report the internal consistency of the factors from their research samples. However, the university sample used in the current study has a reasonably wide demographic range and there is a great deal of research in this area that has used student samples (e.g., Fiebert \& Gonzalez, 1997; Foo \& Margolin, 1995; Nabors, 2010; Riggs \& O'Leary, 1996; Straus, 2008; Straus \& Ramirez, 2004; White \& Koss, 1991), and therefore this scale will be of use in similar future research.

Furthermore, future research could assess additional psychometric properties of the measure, for example, test-retest reliability. Anonymity regarding participant responses precluded test-retest data being obtained during the current research, therefore, the current research is limited in that it is not clear how stable responses to the various NVOBS subscales are over time. Also, the measure should be used in alternative populations, such as prison and community samples, to examine whether the norms identified in the student sample are generalizable to other samples.

It was beyond the scope of the current study to include association with other scales, but further studies will include measures of validity (e.g., convergent, 
discriminant) that are standard in validation papers, to evaluate the generalizability of the scale. For example, it is important to assess how responses to the five subscales relate to responses on widely used measures of trait aggression (e.g., Buss-Perry Aggression Questionnaire, Attitudes toward Violence Against Women) and other measures of IPV.

In conclusion, the questionnaire developed in this study is an improvement and extension of pre-existing measures because it is a comprehensive one that contains comparable questions for all three offense types (general violence, IPV, and non-violent offending), and uses the same response format throughout. The NVOBS appears to be a useful self-report measure of violent and non-violent offending with good psychometric properties.

\section{Appendix 1: Instructions to participants}

\section{IPV}

Sometimes conflict gets out of hand and physical fights occur. Couples have many different ways of trying to settle their differences. This is a list of things that might happen when you have differences. Please use the following scale to answer the questions below. Please read each statement carefully, and then circle the number that corresponds to how many times you did each of these in the last year, and how many times your partner did them in the last year. If your relationship did not last for the whole of the past year, please indicate how many times you and your partner did each of these during your whole relationship.

How often did this happen in the past year?

$\boldsymbol{0}=$ This has never happened, $\mathbf{1}=$ Once in the past year, $\mathbf{2}=$ Twice in the past year, $\mathbf{3}=3-5$ times in the past year, $4=6-10$ times in the past year, $5=11-20$ times in the past year, $\mathbf{6}=$ More than 20 times in the past year.

\section{General violence}

Sometimes conflict gets out of hand and physical fights occur. Please answer the following questions in relation to your behavior. Please do not include fights you have had with a romantic partner (such as a boyfriend/ girlfriend as you have already been asked about this in Q7 1 Section), only include fights with someone other than your partner, for example, friend, family member, stranger, etc.

Please use the following scale to answer the questions below. Please read each statement carefully, and then circle the number that corresponds to your reply.

How often did this happen in the past year? $\boldsymbol{0}=$ This has never happened, $\mathbf{1}=$ Once in the past year, $\mathbf{2}=$ Twice in the past year, $\mathbf{3}=3-5$ times in the past year, $\mathbf{4}=6-10$ times in the past year, $5=11-20$ times in the past year, $\mathbf{6}=$ More than 20 times in the past year.

\section{Non-violent offending}

Please answer the following questions in relation to your behavior.

Please use the following scale to answer the questions below. Please read each statement carefully, and then circle the number that corresponds to your reply.

How often did this happen in the past year?

$\boldsymbol{0}=$ This has never happened, $\mathbf{1}=$ Once in the past year, $\mathbf{2}=$ Twice in the past year, $\mathbf{3}=3-5$ times in the past year, $\mathbf{4}=6-10$ times in the past year, $\mathbf{5}=11-20$ times in the past year, $\mathbf{6}=$ More than 20 times in the past year.

\section{REFERENCES}

Archer, J. (1999). Assessment of the reliability of the Conflict Tactics Scales: A meta-analytic review. Journal of Interpersonal Violence, 14, 1263-1289.

Archer, J. (2000). Sex differences in aggression between heterosexual partners: A meta-analytic review. Psychological Bulletin, 126, 651680.

Archer, J. (2002). Sex differences in physically aggressive acts between heterosexual partners: A meta-analytic review. Aggression and Violent Behavior: A Review Journal, 7, 313-351.

Archer, J. (2004). Sex differences in aggression in real-world settings: A meta-analytic review. Review of General Psychology, 8, 291-322.

Archer, J. (2006). Cross-cultural differences in physical aggression between partners: A social-role analysis. Personality and Social Psychology Review, 10, 133-153.

Archer, J. (2009). Does sexual selection explain human sex differences in aggression? Behavioral and Brain Sciences, 32, 249-266.

Archer, J. (2012). Can evolutionary principles explain patterns of family violence ${ }^{\mathrm{Q} 8}$ ? Psychological Bulletin. Advanced online publication.

Archer, J., Fernández-Fuertes, A. A., \& Thanzami, V. L. (2010). Does costbenefit analysis or self-control predict involvement in two forms of aggression? Aggressive Behavior, 36, 292-304.

Babcock, J. C., Miller, S., \& Siard, C. (2003). Toward a typology of abusive women: Differences between partner-only and generally violent women in the use of violence. Psychology of Women Quarterly, 13, 46-59.

Bendixen, M., \& Olweus, D. (1999). Measurement of antisocial behavior in early adolescence and adolescence: Psychometric properties and substantive findings. Criminal Behaviour and Mental Health, 9, 323-354.

Borjesson, W. I., Aarons, G. A., \& Dunn, M. E. (2003). Development and confirmatory factor analysis of the abuse within intimate relationships scale. Journal of Interpersonal Violence, 18, 295-309.

Busch, A. L., \& Rosenberg, M. S. (2004). Comparing women and men arrested for domestic violence: A preliminary report. Journal of Family Violence, 19, 49-57.

Buzawa, E., Hotaling, G. T., Klein, A., \& Byrne, J. (1999). Response to domestic violence in a proactive court setting. Lowell: University of Massachusetts. 
Cadsky, O., \& Crawford, M. (1988). Establishing batterer typologies in a clinical sample of men who assault their female partners. Canadian Journal of Community Mental Health, 7, 119-127.

Capaldi, D. M., \& Crosby, L. (1997). psychological and physical aggression in young, at-risk couples. Social Development, 6, 184206.

Cattell, R. B. (1966). The scree test for the number of factors. Multivariate Behavioral Research, 1, 245-276.

Cohen, J. (1988). Statistical power analysis for the behavioral sciences (2nd ed.). Hillsdale, NJ: Lawrence Earlbaum Associates.

Conradi, L. M., Geffner, R., Hamberger, L. K., \& Lawson, G. (2009). An exploratory study of women as dominant aggressors of physical violence in their intimate relationships. Journal of Aggression, Maltreatment \& Trauma, 7, 1-6.

Dahlberg, L. L., Toal, S. B., \& Behrens, C. B. (1998). Measuring violencerelated attitudes, beliefs and behaviors amongst youths: A compendium of assessment tools. Atlanta, GA: Division of Violence Prevention, National Center or Injury Prevention and Control, Centers for Disease Control and Prevention.

Daly, M., \& Wilson, M. (1988). Homicide. New York: Aldine De Gruyter.

DeLisi, M., \& Piquero, A. R. (2011). New frontiers in criminal careers research, 2000-2011: A state-of-the-art review. Journal of Criminal Justice, 39, 289-301.

DeLucia, B., Owens, C. E., Will, J. A., \& McCoin, S. (1999). Hubbard House, Inc. domestic offender obtaining reeducation (door) program outcome assessment, final report. Jacksonville: Northeast Florida Centre for Community Initiatives, University of North Florida.

Dobash, R. E., \& Dobash, R. P. (1980). Violence against wives: A case against the patriarchy. London: Open Books.

Dobash, R. E., \& Dobash, R. P. (1992). Women, violence and social change. London: Routledge.

Dobash, R. E., \& Dobash, R. P. (1998). Rethinking violence against women. Thousand Oaks, CA: Sage.

Dobash, R. P., \& Dobash, R. E. (2004). Women's violence to men in intimate relationships: Working on a puzzle. British Journal of Criminology, 44, 324-349.

Dobash, R. P., Dobash, R. E., Cavanagh, K., \& Lewis, R. (1998). Separate and intersecting realities: A comparison of men's and women's accounts of violence against women. Violence Against Women, 4, 382414.

Dobash, R. P., Dobash, R. E., Wilson, M., \& Daly, M. (1992). The myth of sexual symmetry in marital violence. Social Problems, 39, 71-91.

Ehrensaft, M. K., Moffitt, T. E., \& Caspi, A. (2004). Clinically abusive relationships in an unselected birth cohort: Men's and women's participation and developmental antecedents. Journal of Abnormal Psychology, 113, 258-271.

Eme, R. F. (2007). Sex differences in child-onset, life-course-persistent conduct disorder: A review of biological influences. Clinical Psychology Review, 27, 607-627.

Eme, R. F. (2009). Male life-course persistent antisocial behavior: A review of neurodevelopmental factors. Aggression and Violent Behavior, 14, 348-358.

Eme, R. F. (2010). Male life-course-persistent antisocial behavior. Archives of Pediatrics and Adolescent Medicine, 164, 486-487.

Fagan, J. A., Stewart, D. K., \& Hansen, K. V. (1983). Violent men or violent husbands? Background factors and situational correlates. In D. Finkelhor, R. J. Gelles, G. T. Hotaling, \& M. A. Straus (Eds.), The dark side of families: Current family violence research. Beverly Hills, CA: Sage.

Farrington, D. P., Coid, J. W., Harnett, L., Jolliffe, D., Soteriou, N., Turner, R., \& West, D. J. (2006). Criminal careers and life success: New findings from the Cambridge study in delinquent behaviour. Home Office Research study No. 281. London: Home Office.
Felson, R. B. (2002). Violence and gender reexamined. Washington, DC: American Psychological Association.

Fiebert, M. S., \& Gonzalez, D. M. (1997). College women who initiate assaults on their male partners and the reasons offered for such behavior. Psychological Reports, 80, 583-590.

Field, A. (2009). Discovering statistics using SPSS (3rd ed.). UK: Sage.

Finkel, E., DeWall, C. N., Slotter, E. B., Oaten, M., \& Foshee, V. A. (2009). Self-regulatory failure and intimate partner violence perpetration. Journal of Personality and Social Psychology, 97, 483-499.

Foo, L., \& Margolin, G. (1995). A multivariate investigation of dating aggression. Journal of Family Violence, 10, 351-377.

Gardner, W., Mulvey, E. P., \& Shaw, E. C. (1995). Regression analysis of counts and rates: Poisson, overdispersed, and negative binomial models. Psychological Bulletin, 118, 392-404.

Gelles, R. J., \& Straus, M. A. (1979). Determinants of violence in the family: Towards a theoretical integration. In W. R. Burr, R. Hill, F. I. Nye, \& I. L. Reiss (Eds.), Contemporary theories about the family (pp. 549-581). New York: Free Press.

George, M. J. (1994). Riding the donkey backwards: Men as the unacceptable victims of marital violence. Journal of Men's Studies, 3, $137-159$.

Gerber, L. G. (1991). Gender stereotypes and power: Perception and roles in violent marriages. Sex Roles, 24, 439-458.

Giles-Sims, J. (1983). Wife battering: A systems theory approach. New York: Guildford.

Graham-Kevan, N., \& Archer, J. (2003). Physical aggression and control in heterosexual relationships: The effect of sampling. Violence and Victims, 18, 181-198.

Graham-Kevan, N., \& Archer, J. (2009). Control tactics and partner violence in heterosexual relationships. Evolution \& Human Behavior, $30,445-452$.

Gondolf, E. W. (1988). Who are those guys? Towards a behavioral typology of batterers. Violence and Victims, 3, 187-203.

Gottfredson, M. R., \& Hirschi, T. (1990). A general theory of Crime. USA: Stanford University Press.

Gottfredson, M. R., \& Hirschi, T. (2007). A general theory of Crime (3rd ed.). USA: Stanford University Press.

Hay, D. F. (2005). The beginnings of aggression in infancy. In R. E. Tremblay, W. W. Hartup, \& J. Archer (Eds.), Developmental origins of aggression (pp. 107-132). New York: The Guildford Press.

Hayton, J. C., Allen, D. G., \& Scarpello, V. (2004). Factor retention decisions in exploratory factor analysis: A tutorial on parallel analysis. Organizational Research Methods, 7, 191-205.

Henning, K., \& Feder, L. (2004). A comparison of men and women arrested for domestic violence: Who presents the greater threat? Journal of Family Violence, 19, 69-80.

Henning, K., Jones, A., \& Holdford, R. (2003). Treatment needs of women arrested for domestic violence: A comparison with male offenders. Journal of Interpersonal Violence, 18, 839-856.

Higher Education Statistics Agency (HESA). http://www.hesa.ac.uk/ [accessed on April 28, 2011].

Holt, J. (2004). Item parceling in structural equation models for optimum solutions. Paper presented at the 2004 Annual Meeting of the MidWestern Educational Research Association, Columbus, $\mathrm{OH}$.

Holtzworth-Munroe, A., Meehan, C., Herron, K., Rehman, U., \& Stuart, G. L. (2000). Testing the Holtzworth-Munroe and Stuart (1994) Batterer typology. Journal of Consulting and Clinical Psychology, 68, 1000 1019.

Home Office. (2010). User guide to home office crime statistics $^{\text {Q10 }}$. Home Office

Horn, J. L. (1965). A rationale and test for the number of factors in factor analysis. Psychometrika, 30, 179-185.

Hotaling, G. T., Straus, M. A., \& Lincoln, A. J. (1990). Intrafamily violence and crime and violence outside the family. In M. A. Straus \& R. J. 
Gelles (Eds.), Physical violence in American families: Risk factors and adaptations to violence in 8, 145 families (pp. 431-470). New Brunswick: Transaction.

Howard, P., \& Dixon, L. (2011). Developing an empirical classification of violent offences for use in the prediction of recidivism in England and Wales. Journal of Aggression, Conflict and Peace Research, 3, 141154.

Huizinga, D., Esbensen, F., \& Weiher, A. W. (1991). Are there multiple paths to delinquency? The Journal of Criminal Law \& Criminology, 82, 83-118.

Hutchinson, M. K., \& Holtman, M. C. (2005). Analysis of count data using poisson regression. Research in Nursing and Health, 28, 408-418.

Kaiser, H. F. (1974). An index of factorial simplicity. Psychometrika, 39, 31-36.

Kanazawa, S., \& Still, M. C. (2000). Why men commit crimes (and why they desist). Sociological Theory, 18, 434-447.

Klein, P. (1994). An easy guide to factor analysis. London: Routledge.

Krueger, R. F., Moffitt, T. E., Caspi, A., Bleske, A., \& Silva, P. A. (1998). Assortative mating for antisocial behavior: Developmental and methodological implications. Behavior Genetics, 28, $173-186$.

Lussier, P., Farrington, D. P., \& Moffitt, T. E. (2009). Is the antisocial child father of the abusive man? A 40-year prospective longitudinal study on the developmental antecedents of intimate partner violence. Criminology, 47, 741-780.

Mak, A. S. (1993). A self-report delinquency scale for Australian adolescents. Australian Journal of Psychology, 45, 75-79.

Moffitt, T. E., Caspi, A., Krueger, R. F., Magdol, L., Margolin, G., Silva, P. A., \& Sydney, R. (1997). Do partners agree about abuse in their relationship? A psychometric evaluation of interpartner agreement. Psychological Assessment, 9, 47-56.

Moffitt, T. E., Caspi, A., Rutter, M., \& Silva, P. A. (2001). Sex differences in antisocial behaviour. Conduct disorder, delinquency, and violence in the Dunedin longitudinal study. UK: Cambridge University Press.

Moffitt, T. E., Kreuger, R. F., Caspi, A., \& Fagan, J. (2000). Partner abuse and general crime: How are they the same, how are they different? Criminology, 38, 199-232.

Moffitt, T. E., \& Silva, P. A. (1988). Self-reported delinquency: Results from an instrument for New Zealand. Australia \& New Zealand Journal of Criminology, 21, 227-240.

Nabors, E. (2010). Drug use and intimate partner violence among college students: An in-depth exploration. Journal of Interpersonal Violence, $25,1043-1063$.

Pedhazur, E., \& Schmelkin, L. (1991). Measurement, design and analysis: An integrated approach. Hillsdale, NJ: Erlbaum.

Pratt, T. C., \& Cullen, F. T. (2000). The empirieal status of Gottfredson and Hirsehi's general theory of erime:A meta analysis.Criminology, 38,931 964.

Richardson, D. R., \& Green, L. R. (1999). Social sanction and threat explanations of gender effects on direct and indirect aggression. Aggressive Behavior, 25, 425-434.

Richardson, D. R., \& Green, L. R. (2003). Defining direct and indirect aggression: The Richardson Conflict Response Questionnaire. International Review of Social Psychology, 16, 11-30.

Riggs, D. S., \& O’Leary, K. D. (1996). Aggression between heterosexual dating partners: An examination of a causal model of courtship aggression. Journal of Interpersonal Violence, 11, 519-540.
Shields, N. M., McCall, G. J., \& Hanneke, C. R. (1988). Patterns of family and nonfamily violence: Violent husbands and violent men. Violence and Victims, 3, 83-97.

Steffensmeier, D., \& Allan, E. (1996). Gender and crime: Toward a gendered theory of female offending. Annual Review of Sociology, 22, 459-487.

Stevens, J. P. (1992). Applied multivariate statistics for the social sciences (2nd ed.). USA: Earlbaum.

Straus, M. A. (1979). Measuring intrafamily conflict and violence: The conflict tactics (CT) scales. Journal of Marriage and the Family, 41, $75-88$.

Straus, M. A. (1990). Measuring intrafamily conflict and violenee: The Confliet Tacties (CT) Seales. In M. A. Straus \& R. J. Gelles (Eds.), Physical violence in American families: Risk factors and adaptations to violence in 8,145 families (pp. 29-47). New Brunswick, NJ: Fransaetion.

Straus, M. A. (2008). Dominance and symmetry in partner violence by male and female university students in 32 nations. Children and Youth Services Review, 30, 252-275.

Straus, M. A., Hamby, S. L., Boney-McCoy, S., \& Sugarman, D. B. (1996). The revised Conflict Tactics Scales (CTS2): Development and preliminary psychometric data. Journal of Family Issues, 17, 283-316.

Straus, M. A., \& Ramirez, I. L. (2004). Criminal history and assault of dating partners: The role of type of prior crime, age of onset, and gender. Violence and Victims, 19, 413-434.

Tabachnick, B. G., \& Fidell, L. S. (2007). Using multivariate statistics (5th ed.). USA: Pearson Education.

Thornton, A. J. V., Graham-Kevan, N., \& Archer, J. (2010). Adaptive and maladaptive personality traits as predictors of violent and non-violent offending behavior in men and women. Aggressive Behavior, 36, 177 186.

Tremblay, R. E., Nagin, D. S., Séguin, J. R., Zoccolillo, M., Zelazo, P. D., Boivin, M., ... Japel, C. (2004). Physical aggression during early childhood: Trajectories and predictors. Pediatrics, 114, 43-50.

Vaughn, M. G., DeLisi, M., Gunter, T., Fu, Q., Beaver, K. M., Perron, B. E., \& Howard, M. O. (2011). The severe 5\%: A latent class analysis of the externalizing behavior spectrum in the United States. Journal of Criminal Justice, 39, 75-80.

Vaughn, M. G., Fu, Q., Wernet, S. J., DeLisi, M., Beaver, K. M., Perron, B. E., \& Howard, M. O. (2011). Characteristics of abstainers from substance use,antisocial behavior in the United States. Journal of Criminal Justice, 39, 212-217.

Walsh, A. (2000). Evolutionary psychology and the origins of justice. Justice Quarterly, 17, 841-864.

White, J. W., \& Koss, M. P. (1991). Courtship violence: Incidence in a national sample of higher education students. Violence and Victims, 6 , 247-256

Wilson, M. I., \& Daly, M. (1985). Competitiveness, risk taking, and violence: The young male syndrome. Ethology and Sociobiology, 6, 59-73.

Wilson, M. I., \& Daly, M. (1992). The man who mistook his wife for a chattel. In J. H. Barkow, L. Cosmides, \& J. Tooby (Eds.), The adapted mind (pp. 289-321). New York: Oxford University Press.

Wilson, M. I., \& Daly, M. (1996). Male sexual proprietariness against wives. Current Directions in Psychological Science, 5, 2-7. 


\section{AUTHOR QUERY FORM}

\section{JOURNAL: AGGRESSIVE BEHAVIOR}

\section{Article: ab21468}

Dear Author,

During the copyediting of your paper, the following queries arose. Please respond to these by annotating your proofs with the necessary changes/additions using the E-annotation guidelines attached after the last page of this article.

We recommend that you provide additional clarification of answers to queries by entering your answers on the query sheet, in addition to the text mark-up.

\begin{tabular}{|c|c|c|}
\hline Query No. & Query & Remark \\
\hline Q1 & Please provide the educational degrees of the corresponding author. & \\
\hline Q2 & Please check the insertion of the heading 'Introduction'. & \\
\hline Q3 & $\begin{array}{l}\text { References Broidy et al., } 2003 \text { and Côté, Tremblay, Nagin, Zoccolillo, \& Vitaro, } \\
2002 \text { have not been included in the Reference List, please supply full publication } \\
\text { details. }\end{array}$ & \\
\hline Q4 & $\begin{array}{l}\text { Hilbe, } 2007 \text { has not been included in the Reference List, please supply full } \\
\text { publication details. }\end{array}$ & \\
\hline Q5 & $\begin{array}{l}\text { Smith \& Visher, } 1980 \text { has not been included in the Reference List, please supply } \\
\text { full publication details. }\end{array}$ & \\
\hline Q6 & $\begin{array}{l}\text { Payne, Higgins, and Blackwell (2010) has not been included in the Reference } \\
\text { List, please supply full publication details. }\end{array}$ & \\
\hline Q7 & $\begin{array}{l}\text { The headings are unnumbered hence Section } 1 \text { has been changed to Introduction } \\
\text { Section, please check. }\end{array}$ & \\
\hline Q8 & Please provide the volume number and page range. & \\
\hline Q9 & $\begin{array}{l}\text { Please cite the following references in the text or else delete them from the } \\
\text { reference list: Capaldi and Crosby, 1997; Krueger et al., 1998; Pratt and Cullen, } \\
\text { 2000; Straus, 1990. }\end{array}$ & \\
\hline Q10 & Please provide the publisher location. & \\
\hline
\end{tabular}


Required software to e-Annotate PDFs: Adobe Acrobat Professional or Adobe Reader (version 8.0 or above). (Note that this document uses screenshots from Adobe Reader $\mathrm{X}$ )

The latest version of Acrobat Reader can be downloaded for free at: http://get.adobe.com/reader/

Once you have Acrobat Reader open on your computer, click on the Comment tab at the right of the toolbar:

닙

This will open up a panel down the right side of the document. The majority of tools you will use for annotating your proof will be in the Annotations section, pictured opposite. We've picked out some of these tools below:

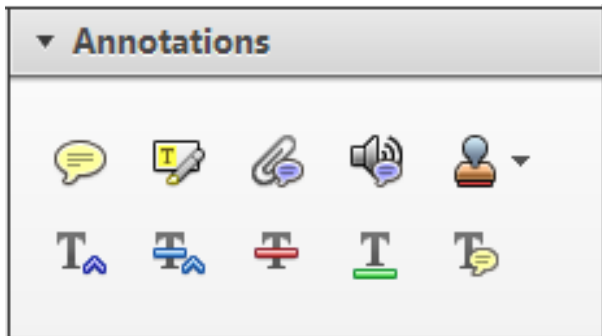

1. Replace (Ins) Tool - for replacing text.

Strikes a line through text and opens up a text box where replacement text can be entered.

\section{How to use it}

- Highlight a word or sentence.

- Click on the Replace (Ins) icon in the Annotations section.

- Type the replacement text into the blue box that appears.

Idard tramework for the analysis of $\mathrm{m}$ icy-Nevertheless, it also led to exog،

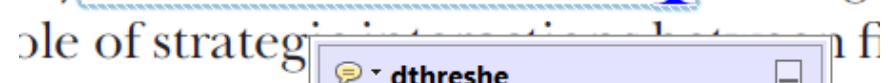
aber of comp 08/06/2011 15:58:17

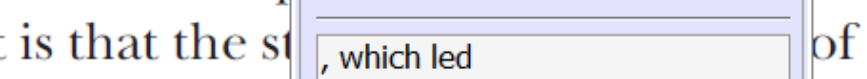
nain compo: be level, are exc nc

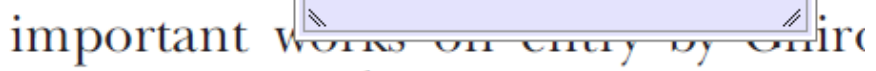
M heneferth) ${ }^{1}$ we anen the 'hlark $\mathrm{h}$

3. Add note to text Tool - for highlighting a section to be changed to bold or italic.

T Highlights text in yellow and opens up a text box where comments can be entered.

\section{How to use it}

- Highlight the relevant section of text.

- Click on the Add note to text icon in the Annotations section.

- Type instruction on what should be changed regarding the text into the yellow box that annears.

namic responses of mark ups ent with the VAR evidence

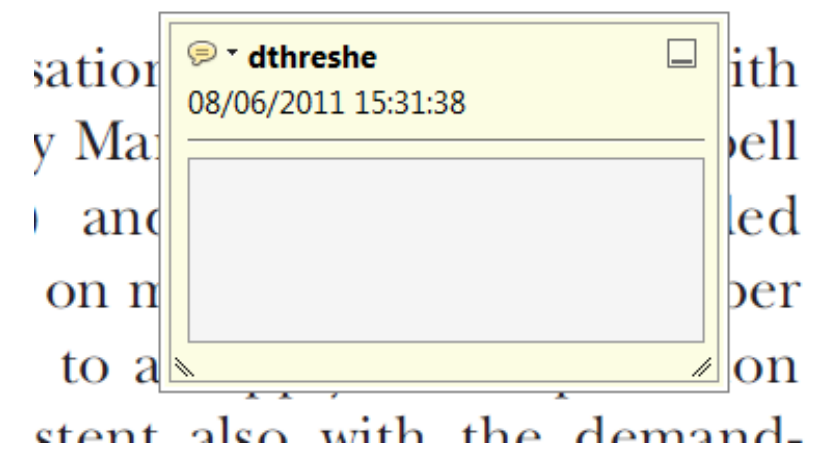

2. Strikethrough (Del) Tool - for deleting text.

Thikes a red line through text that is to be deleted.

\section{How to use it}

- Highlight a word or sentence.

- Click on the Strikethrough (Del) icon in the Annotations section.

there is no room tor extra prohts al c ups are zero and the number of ret) values are not determined by Blanchard and Kiyotaki (1987), rfect competition in general equilil ts of aggregate demand and supply lassical framework assuming monol eon an evorenois number of firms

\section{Add sticky note Tool - for making notes at} specific points in the text.

Marks a point in the proof where a comment needs to be highlighted.

\section{How to use it}

- Click on the Add sticky note icon in the Annotations section.

- Click at the point in the proof where the comment should be inserted.

- Type the comment into the yellow box that appears.

lallu allu suppiy silucks. hivst vi

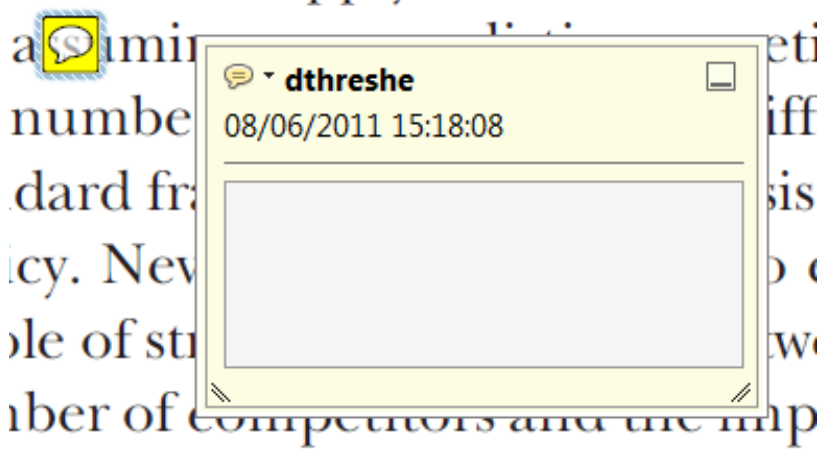

is that the structure of the secto 
5. Attach File Tool - for inserting large amounts of text or replacement figures.

Inserts an icon linking to the attached file in the appropriate pace in the text.

How to use it

- Click on the Attach File icon in the Annotations section.

- Click on the proof to where you'd like the attached file to be linked.

- Select the file to be attached from your computer or network.

- Select the colour and type of icon that will appear in the proof. Click OK.

E N D

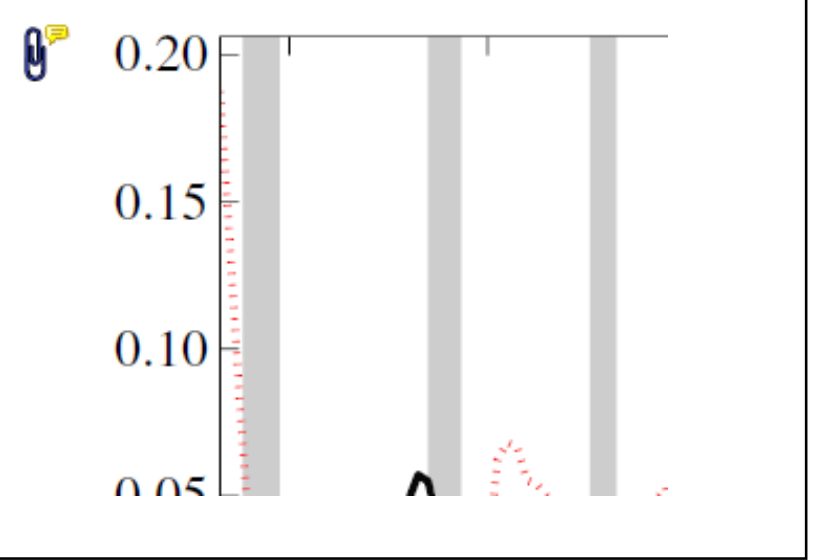

6. Add stamp Tool - for approving a proof if no corrections are required.

- Inserts a selected stamp onto an appropriate place in the proof

\section{How to use it}

- $\quad$ Click on the Add stamp icon in the Annotations section.

- $\quad$ Select the stamp you want to use. (The Approved stamp is usually available directly in the menu that appears).

- Click on the proof where you'd like the stamp to appear. (Where a proof is to be approved as it is, this would normally be on the first page).

of the Dusiness cycie, starting with the on perfect competition, constant ret

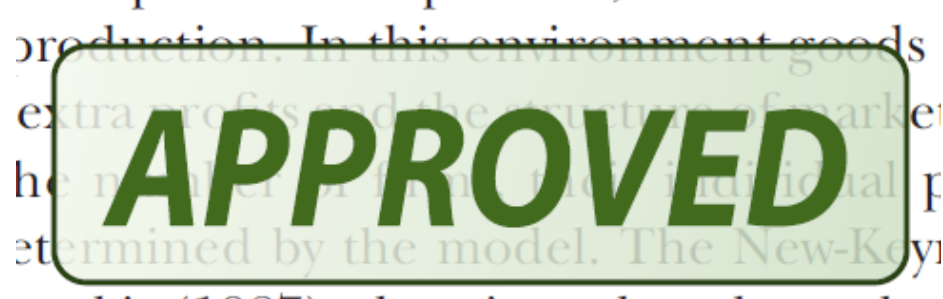

otaki (1987), has introduced produc general equilibrium models with nomin
- Drawing Markups

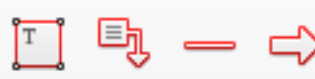

$0 \square \sqrt{6} D$

\section{How to use it}

- Click on one of the shapes in the Drawing Markups section.

- Click on the proof at the relevant point and draw the selected shape with the cursor.

- To add a comment to the drawn shape, move the cursor over the shape until an arrowhead appears.

- Double click on the shape and type any text in the red box that appears.
7. Drawing Markups Tools - for drawing shapes, lines and freeform annotations on proofs and commenting on these marks.

Allows shapes, lines and freeform annotations to be drawn on proofs and for comment to be made on these marks.

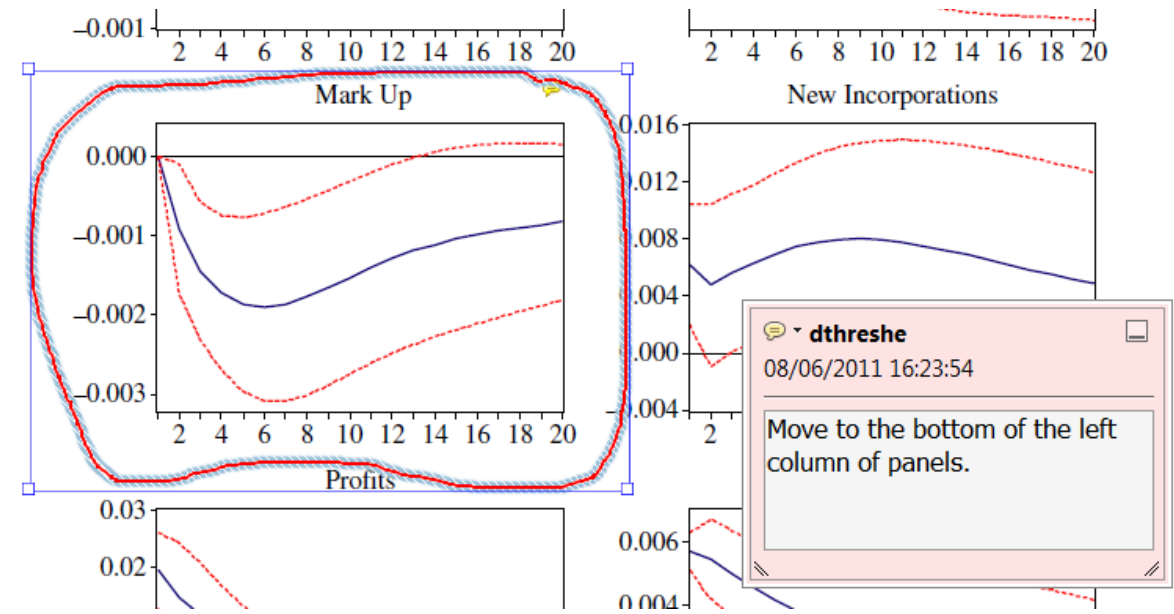

For further information on how to annotate proofs, click on the Help menu to reveal a list of further options:

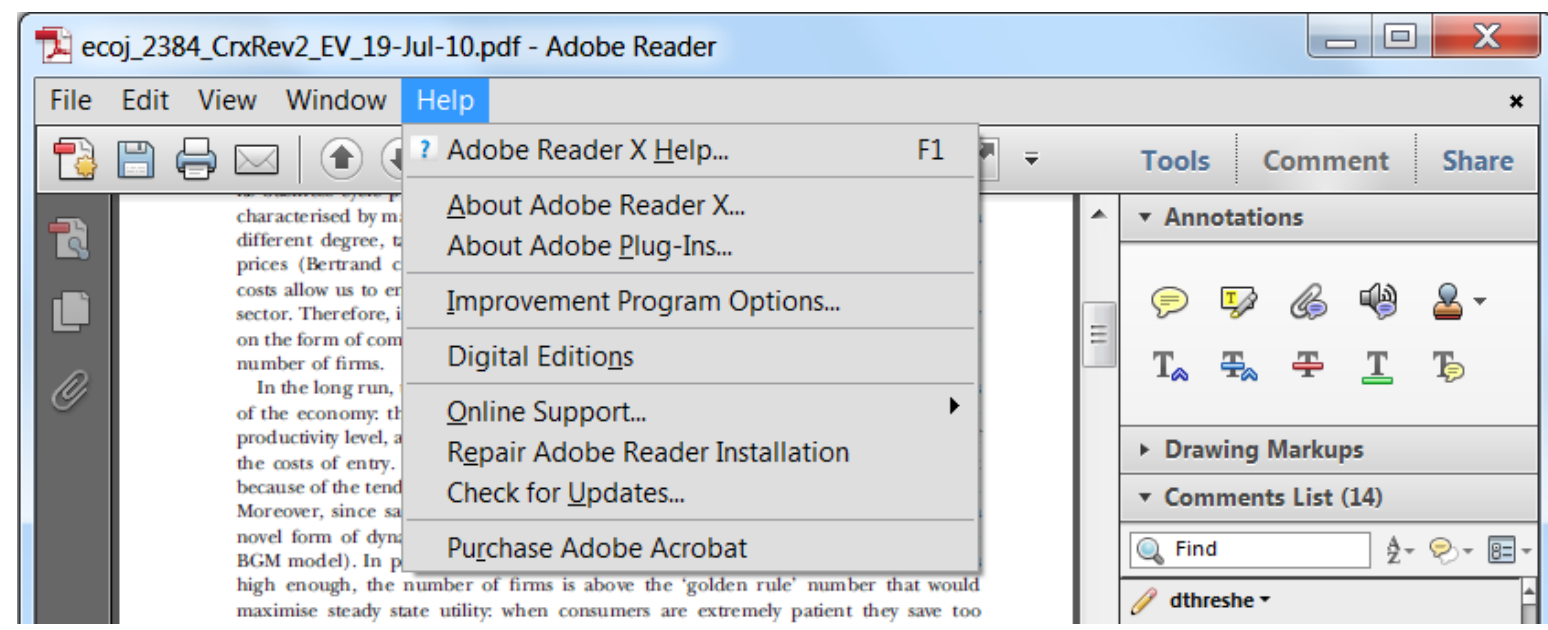




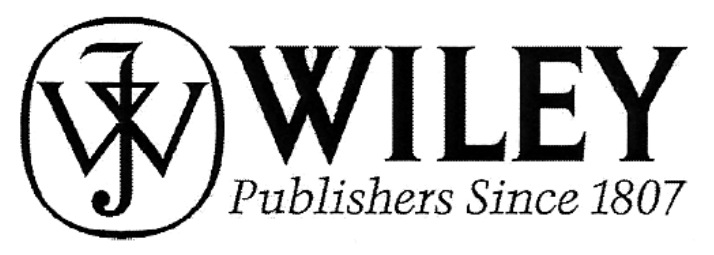

\section{COLOR REPRODUCTION IN YOUR ARTICLE}

Color figures were included with the final manuscript files that we received for your article. Because of the high cost of color printing, we can only print figures in color if authors cover the expense.

Please indicate if you would like your figures to be printed in color or black and white. Color images will be reproduced online in Wiley Online Library at no charge, whether or not you opt for color printing.

Failure to return this form will result in the publication of your figures in black and white.

JOURNAL

AGGRESSIVE BEHAVIOR

VOLUME

ISSUE

TITLE OF MANUSCRIPT

MS. NO.

NO. OF

COLOR PAGES AUTHOR(S)

\begin{tabular}{|c|c|c|c|c|c|}
\hline No. Color Pages & Color Charges & No. Color Pages & Color Charges & No. Color Pages & Color Charges \\
\hline 1 & 950 & 5 & 3400 & 9 & 10 \\
5850 & 6350 \\
3 & 1450 & 6 & 3900 & 4400 & 11 \\
4 & 1950 & 7 & 4900 & 12 & 7350 \\
& 2450 & 8 & & \\
\hline
\end{tabular}

$\square \quad$ Please print my figures in black and white

$\square$ Please print my figures in color

**International orders must be paid in currency and drawn on a U.S. bank

Please check one: $\square$ Check enclosed $\square$ Bill m

If credit card order, charge to:

Credit Card No

BILL TO:

Name

Institution

Address
Signature
$\$$

Credit Card

MasterCard Exp. Date

Purchase Order No. Phone

Fax

E -mail 
Date:

Contributor name:

Contributor address:

Manuscript number (Editorial office only):

Re: Manuscript entitled

(the "Contribution")

for publication in (the "Journal")

published by ("Wiley-Blackwell").

Dear Contributor(s):

Thank you for submitting your Contribution for publication. In order to expedite the editing and publishing process and enable Wiley-Blackwell to disseminate your Contribution to the fullest extent, we need to have this Copyright Transfer Agreement signed and returned as directed in the Journal's instructions for authors as soon as possible. If the Contribution is not accepted for publication, or if the Contribution is subsequently rejected, this Agreement shall be null and void. Publication cannot proceed without a signed copy of this Agreement.

\section{A. COPYRIGHT}

1. The Contributor assigns to Wiley-Blackwell, during the full term of copyright and any extensions or renewals, all copyright in and to the Contribution, and all rights therein, including but not limited to the right to publish, republish, transmit, sell, distribute and otherwise use the Contribution in whole or in part in electronic and print editions of the Journal and in derivative works throughout the world, in all languages and in all media of expression now known or later developed, and to license or permit others to do so.

2. Reproduction, posting, transmission or other distribution or use of the final Contribution in whole or in part in any medium by the Contributor as permitted by this Agreement requires a citation to the Journal and an appropriate credit to Wiley-Blackwell as Publisher, and/or the Society if applicable, suitable in form and content as follows: (Title of Article, Author, Journal Title and Volume/Issue, Copyright @ [year], copyright owner as specified in the Journal). Links to the final article on Wiley-Blackwell's website are encouraged where appropriate.

\section{B. RETAINED RIGHTS}

Notwithstanding the above, the Contributor or, if applicable, the Contributor's Employer, retains all proprietary rights other than copyright, such as patent rights, in any process, procedure or article of manufacture described in the Contribution.

\section{PERMITTED USES BY CONTRIBUTOR}

1. Submitted Version. Wiley-Blackwell licenses back the following rights to the Contributor in the version of the Contribution as originally submitted for publication:

a. After publication of the final article, the right to self-archive on the Contributor's personal website or in the Contributor's institution's/employer's institutional repository or archive. This right extends to both intranets and the Internet. The Contributor may not update the submission version or replace it with the published Contribution. The version posted must contain a legend as follows: This is the pre-peer reviewed version of the following article: FULL CITE, which has been published in final form at [Link to final article].

b. The right to transmit, print and share copies with colleagues.

2. Accepted Version. Re-use of the accepted and peer-reviewed (but not final) version of the Contribution shall be by separate agreement with WileyBlackwell. Wiley-Blackwell has agreements with certain funding agencies governing reuse of this version. The details of those relationships, and other offerings allowing open web use, are set forth at the following website: http://www.wiley.com/go/funderstatement. NIH grantees should check the box at the bottom of this document.
3. Final Published Version. Wiley-Blackwell hereby licenses back to the Contributor the following rights with respect to the final published version of the Contribution:

a. Copies for colleagues. The personal right of the Contributor only to send or transmit individual copies of the final published version in any format to colleagues upon their specific request provided no fee is charged, and further-provided that there is no systematic distribution of the Contribution, e.g. posting on a listserve, website or automated delivery.

b. Re-use in other publications. The right to re-use the final Contribution or parts thereof for any publication authored or edited by the Contributor (excluding journal articles) where such re-used material constitutes less than half of the total material in such publication. In such case, any modifications should be accurately noted.

c. Teaching duties. The right to include the Contribution in teaching or training duties at the Contributor's institution/place of employment including in course packs, e-reserves, presentation at professional conferences, in-house training, or distance learning. The Contribution may not be used in seminars outside of normal teaching obligations (e.g. commercial seminars). Electronic posting of the final published version in connection with teaching/training at the Contributor's institution/place of employment is permitted subject to the implementation of reasonable access control mechanisms, such as user name and password. Posting the final published version on the open Internet is not permitted.

d. Oral presentations. The right to make oral presentations based on the Contribution.

4. Article Abstracts, Figures, Tables, Data Sets, Artwork and Selected Text (up to 250 words).

a. Contributors may re-use unmodified abstracts for any non-commercial purpose. For on-line uses of the abstracts, Wiley-Blackwell encourages but does not require linking back to the final published versions.

b. Contributors may re-use figures, tables, data sets, artwork, and selected text up to 250 words from their Contributions, provided the following conditions are met:

(i) Full and accurate credit must be given to the Contribution.

(ii) Modifications to the figures, tables and data must be noted. Otherwise, no changes may be made.

(iii) The reuse may not be made for direct commercial purposes, or for financial consideration to the Contributor.

(iv) Nothing herein shall permit dual publication in violation of journal ethical practices. 


\section{CONTRIBUTIONS OWNED BY EMPLOYER}

1. If the Contribution was written by the Contributor in the course of the Contributor's employment (as a "work-made-for-hire" in the course of employment), the Contribution is owned by the company/employer which must sign this Agreement (in addition to the Contributor's signature) in the space provided below. In such case, the company/employer hereby assigns to Wiley-Blackwell, during the full term of copyright, all copyright in and to the Contribution for the full term of copyright throughout the world as specified in paragraph A above.

2. In addition to the rights specified as retained in paragraph $B$ above and the rights granted back to the Contributor pursuant to paragraph $C$ above, WileyBlackwell hereby grants back, without charge, to such company/employer, its subsidiaries and divisions, the right to make copies of and distribute the final published Contribution internally in print format or electronically on the Company's internal network. Copies so used may not be resold or distributed externally. However the company/employer may include information and text from the Contribution as part of an information package included with software or other products offered for sale or license or included in patent applications. Posting of the final published Contribution by the institution on a public access website may only be done with Wiley-Blackwell's written permission, and payment of any applicable fee(s). Also, upon payment of Wiley-Blackwell's reprint fee, the institution may distribute print copies of the published Contribution externally.

\section{E. GOVERNMENT CONTRACTS}

In the case of a Contribution prepared under U.S. Government contract or grant, the U.S. Government may reproduce, without charge, all or portions of the Contribution and may authorize others to do so, for official U.S. Govern- ment purposes only, if the U.S. Government contract or grant so requires. (U.S. Government, U.K. Government, and other government employees: see notes at end)

\section{F. COPYRIGHT NOTICE}

The Contributor and the company/employer agree that any and all copies of the final published version of the Contribution or any part thereof distributed or posted by them in print or electronic format as permitted herein will include the notice of copyright as stipulated in the Journal and a full citation to the Journal as published by Wiley-Blackwell.

\section{G. CONTRIBUTOR'S REPRESENTATIONS}

The Contributor represents that the Contribution is the Contributor's original work, all individuals identified as Contributors actually contributed to the Contribution, and all individuals who contributed are included. If the Contribution was prepared jointly, the Contributor agrees to inform the co-Contributors of the terms of this Agreement and to obtain their signature to this Agreement or their written permission to sign on their behalf. The Contribution is submitted only to this Journal and has not been published before. (If excerpts from copyrighted works owned by third parties are included, the Contributor will obtain written permission from the copyright owners for all uses as set forth in WileyBlackwell's permissions form or in the Journal's Instructions for Contributors, and show credit to the sources in the Contribution.) The Contributor also warrants that the Contribution contains no libelous or unlawful statements, does not infringe upon the rights (including without limitation the copyright, patent or trademark rights) or the privacy of others, or contain material or instructions that might cause harm or injury.

\section{CHECK ONE BOX:}

Contributor-owned work ATTACH ADDITIONAL SIGNATURE PAGES AS NECESSARY

Contributor's signature

Date

Type or print name and title

Type or print name and title

Company/Institution-owned work

(made-for-hire in the course of employment) which is an official U.S. Government publication, is called a "U.S. Government work," and is in the public domain in the United States. In such case, the employee may cross out Paragraph A. 1 but must sign (in the Contributor's signature line) and return this Agreement. If the Contribution was not prepared as part of the employee's duties or is not an official U.S. Government publication, it is not a U.S. Government work. U.K. Government work
(Crown Copyright)

\section{Note to U.K. Government Employees}

The rights in a Contribution prepared by an employee of a U.K. government department, agency or other Crown body as part of his/her official duties, or which is an official government publication, belong to the Crown. U.K. government authors should submit a signed declaration form together with this Agreement. The form can be obtained via http://www.opsi.gov.uk/advice/crown-copyright/copyright-guidance/ publication-of-articles-written-by-ministers-and-civil-servants.htm

\footnotetext{
Other Government work
}

If your status as a government employee legally prevents you from signing this Agreement, please contact the editorial office. 